\title{
TRANSITION TRAUMA METAPHOR IN TRANSGENDER NARRATIVE
}

\author{
Alla Martynyuk \\ https://orcid.org/0000-0003-2804-3152 \\ Scopus Author ID: $\underline{57197721023}$ \\ allamartynyuk@ukr.net \\ V. N. Karazin Kharkiv National University, Ukraine
}

Received December 20, 2020; Revised May 21, 2021; Accepted June 1, 2021

\begin{abstract}
This study combines methodological tools of conceptual metaphor theory and narrative psychology with theoretical assumptions of the intersubjective psycholinguistic approach to meaning to explore instantiations of transition narrative metaphors in 16 TED talks given by transgender people and posted on the TED platform within the period between January 2013 and July 2020. The speakers are aged from 20 to 70; 8 males and 8 females; 2 black and 9 white Americans, 2 Filipinos, 1 black South-African, 1 Puerto Rican, and 1 white Australian. The study offers a new interpretation of narrative metaphor based on the intersubjective model of meaning. Within this model, narrative metaphor is conceived as extended conceptual metaphor instantiated in a number of multimodal metaphoric expressions made coherent by the textual, social, cultural, and historical context of the narrative, but primarily by its interactive situational context, which includes the audience into the narrative through empathy and gives them power to change the narrative. The research reveals that all the 16 analysed narratives rest on the TRANSITION IS CONTEST narrative metaphor that represents a conflict between positive self-evaluation of transition by a transgender individual and its negative evaluation / unacceptance by the society, which makes transition a traumatic experience. The density of words and phrases instantiating the CONTEST metaphor in the 16 narratives varies from 2.5 to $3 \%$ which means that they are key linguistic expressions of the narratives. The CONTEST metaphor provides a deeper insight into transgender transition compared to the JOURNEY/TRAVEL metaphor found to represent transition experience in existing cognitive linguistic and transgender studies. The JOURNEY/TRAVEL metaphor fails to grasp the intersubjective and, consequently, traumatic nature of transition experience. The results of the research suggest that narrative as well as narrative metaphor can be given a more accurate interpretation if they are approached from the intersubjective perspective, which reflects their true nature as socially and culturally shaped interactive phenomena.
\end{abstract}

Keywords: intersubjective model of meaning, metaphor, narrative, transgender, trauma.

\begin{abstract}
Мартинюк Алла. Метафора травматичного досвіду зміни гендеру у трансгендерному наративі.

Анотація. У статті на основі поєднання методологічних інструментів теорії концептуальної метафори та наративної психології, з опорою на методологічні засади інтерсуб'єктивного психолінгвістичного розуміння значення досліджуються наративні метафори, відображені у 16 виступах трансгендерних індивідів на TED-конференціях, опублікованих на платформі TED у період з січня 2013 по липень 2020. Наратори представляють вікові категорії від 20 до 70 років; серед них є 8 чоловіків і 8 жінок; 2 білих і 9 темношкірих американців, 2 філіппінців, 1 темношкірий південноафриканець,
\end{abstract}

(C) Martynyuk, Alla, 2021. This is an Open Access article distributed under the terms and conditions of the Creative Commons Attribution 4.0 International Licence (http://creativecommons.org/licenses/by/4.0).

East European Journal of Psycholinguistics, 8(1), 70-82. https://doi.org/10.29038/eejpl.2021.8.1.mar 
1 пуерторіканець, і 1 біла австралійка. Спираючись на інтерсуб'єктивну модель смислотворення, автор пропонує нову інтерпретацію наративної метафори як розширеної концептуальної метафори, втіленої численними мультимодальними метафоричними засобами, які набувають узгодженості у текстовому, соціальному, культурному та історичному контексті наративу, i, що найголовніше, в інтерактивному ситуативному контексті, який через емпатію включає в наратив аудиторію i надає їй силу змінювати зміст наративу. Згідно з результатами розвідки, усі 16 аналізованих наративів втілюють наративну метафору ЗМІНА ГЕНДЕРНОЇ ІДЕНТИЧНОСТІ $є$ ПРОТИСТОЯННЯ, яка репрезентує конфлікт між трансгендерним індивідом, який позитивно оцінює свій досвід зміни гендеру, і суспільством, яке оцінює його негативно / не приймає, що робить цей досвід травматичним. Щільність слів та словосполучень, які вербалізують метафору ПРОТИСТОЯННЯ в 16 аналізованих наративах, сягає 2,5-3\%, що свідчить про те, що вони $\epsilon$ ключовими для всіх наративів. Метафора ПРОТИСТОЯННЯ надає більш точну інтерпретацію досвіду зміни гендерної ідентичності порівняно з метафорою ПОДОРОЖІ, яка розглядається в існуючих розвідках 3 когнітивної лінгвістики та трансгендерних студіях. Метафора ПОДОРОЖІ не відображає інтерсуб'єктивної і відтак травматичної природи досвіду зміни гендерної ідентичності. Результати дослідження доводять, що наратив, як i наративна метафора можуть бути осмисленими лише на основі інтерсуб'єктивної моделі значення, яка відображає їх природу як соціально і культурно сконструйованих інтерактивних феноменів.

Ключові слова: інтерсуб'єктивна модель значення, метафора, наратив, травма, трансгендер.

\section{Introduction}

Taken separately, transgenderism, metaphor, and narrative are most popular objects of scientific investigation. Especially extensive is a psycholinguistic research on transgenderism exploring how one's gender presentation is perceived in different modalities and environments (see, for example, Bodoin, Berd, \& Adler, 2014; Booz, Dorman, \& Walden, 2017; Hardy et al, 2020). Some attention has been given to transgender metaphor in philosophy, psychology, aesthetics, cultural, gender and transgender studies (Halberstam, 1998; Prosser, 1998; Riley, 2000; Heath, 2006; Hines, 2007; Salamon, 2010; Aizura, 2012; Koch-Rein, 2014). The scholars have focused on the importance of metaphor for grasping transgender experience in the context of a wider discussion of transgender history, psychophysical basis, sociocultural implications, politics, practices, and social attitudes. However, there are practically no papers in the frame of narrative psychology, which would reveal assumptions, feelings, and drives that are hidden behind metaphoric linguistic expressions employed by transgender individuals to talk about their transition experience, i.e. a change from male to female or from female to male.

In a cognitive linguistics paper, Lederer (2015), who investigated transgender individuals' posts from Internet forums and YouTube, discovered that the key metaphor of conceiving and expressing transgender transition is based on the JOURNEY cognitive model. Within this model, transition is understood as movement between the gender categories, male and female, represented as bounded regions in space (CONTAINERS). It is an expected conclusion being in full 
harmony with the claim of the founders of the conceptual metaphor theory (Lakoff \& Johnson, 1980) that people tend to conceptualise transitions between the stages of their lives, relationships and even arguments as JOURNEYS. See, for example, (Arenas \& Essam, 2018) who discuss romantic relationship in terms of the TRAVEL/JOURNEY conceptual metaphor. Transgender scholars (Prosser, 1998; Halberstam, 1998) have also conceptualised transition experience in terms of TRAVEL, BORDERS and HOME.

However, it seems that mapping TRANSGENDER TRANSITION experience as JOURNEY/TRAVEL is not quite accurate for at least two reasons. Firstly, the JOURNEY/TRAVEL metaphor does not grasp the traumatic nature of transgender transition representing it as a routine, ordinary happening that is familiar to the average person. Secondly, this metaphor fails to grasp the intersubjective nature of transgender transition representing it as a purely subjective experience. Yet, if we go deeper into the context of transgender narrative, we will see that the inner subjective experience of transgender transition is shaped by the outer social world, the way other people react to a transgender person. Moreover, the unacceptance of a transgender individual by the outer social world makes their transition a traumatic experience.

We can get a deeper insight into transgender transition metaphor if we go beyond abstract cognitive modelling and turn to the framework of psycholinguistics as a part of the interdisciplinary field of advanced cognitive science that gives rise to an intersubjective model of meaning making (Trevarthen, 1998; Hardy, 1998; Gallagher, 2005; Zahavi, 2005; Thompson, 2007; Zlatev, Racine, Sinha, \& Itkonen, 2008; Zalevskaya, 2014). Within this model, meaning making is conceived as a range of socially and culturally shaped psychophysiological processes, which are part of our interaction with the environment, and which are governed by our needs and goals and transcend rational thinking to include affect/emotion, intuition, and insight in combination with free will; see more in (Martynyuk, 2017).

The aim of this paper is to combine the assumptions of the intersubjective psycholinguistic approach to meaning with the tools of cognitive linguistics and narrative psychology to reveal the inner structures shaping metaphoric expression of transition experience in transgender narrative.

The innovative perspective of the paper is accounted for by a new interpretation of narrative metaphor as multimodal conceptual metaphor with agentive potential, which is instantiated in cohesive linguistic expressions and representations of other modes conceived as coherent within the situational as well as social, cultural and historical context of the narrative.

\section{Theoretical prerequisites}

If we turn to dictionaries, which are mostly helpful when we deal with such high complexity phenomena as narrative, we will discover the two constitutive features that underlie its countless definitions in psychology, philosophy of mind, literature theory, cognitive poetics, anthropology, history, theology, sociology, 
gender studies, and other social sciences. A narrative presupposes: a) telling a story, i.e. giving a spoken or written account of a series of events; b) a particular way of representing events to reflect or conform to an overarching set of aims or values (Cambridge dictionary, s. a.; Oxford English dictionary, s. a.)

A typical narrative is addressed as a spoken or written story, which "provides a coherent causal account of an event that has occurred or that is expected to occur" (Murray, 2003, p. 98). The story is given its structure and coherence by a plot, which connects the beginning to the end and arranges the story into the stages of setup, peak, nadir, and resolution.

It is important to grasp from the start that narrative has two planes. One is the outer, material plane of the social action; it is something that we do or make, and also something that we can perceive - like a coming out speech or a painting. The other plane is inner, psychological; it involves mental structures and processes that motivate the social action and make it possible.

This inner, psychological plane of narrative is described as a specific natural way of thinking and making sense of the world as well as of one's own self. Bruner (1986) called it the narrative mode and opposed to the logical scientific mode. Contrary to the logical scientific mode, which searches for universal truth and works with empirical evidence employing methods of formal logic, the narrative mode creates a life-like representation of the world by making connections between events and their consequences over time through stories.

Bruner (ibid.) distinguished between two psychological "landscapes" of narrative: the landscape of action (mental representation of the actors, intentions or goals, means, and situation of the social action) and the landscape of consciousness (what the actors know, feel and think). The capacity of a human mind to see the connection between the past and present events and predict the perspectives of their development that underlies the narrative mode makes narrative the central means of human cognition. Human beings shape their identity and make sense of the surrounding world through narratives in social interaction. This assumption has become the core of narrative psychology (Bruner, 1986; 1990; Sabrin, 1986; Polkinghorne, 1988; Ricoeur, 1989; Murray, 2003). Moreover, narrative scholars state that psychologically life itself is a narrative achievement (Bruner, 1987; Ricoeur, 1989)

As for the outer, material plane of narrative, we should not think of it as a purely verbal phenomenon even though the social medium of natural language is defining. Taking into account the range of referents of the term "narrative" in contemporary scientific discourse, we can assume that the "story" is multimodal and multimedial. It embraces all the manifestations of the human inner world, which are translated through all existing media and which we can perceive through all our modalities.

Being individual and deeply personal, narratives are always socially and culturally shaped. Every culture has its range of plot lines that individuals can draw on to shape their experience. Moreover, no societal narrative can be valueneutral since every society rests on relations of power and "adoption of dominant 
narratives becomes a means of social discipline" (Murray, 2003, p. 99). Naturally, individual experience does not always conform to the dominant stories since in many cases individual axiological systems radically differ from the mainstream society values. Consequently, individuals are forced to create new, alternative stories that challenge the dominant plot lines.

However, another important thing to grasp is that narrative is an intersubjective phenomenon: as social beings, organising our experience in a narrative form, we seek an empathic response from the others, we want to be paid attention to, understood, and appreciated, we want our experiences to be shared and approved. It also means that creating alternative narratives, individuals can never be free from the pressure of the society that judges them and either accepts or pushes away. Moreover, social unacceptance accounts for traumatic nature of individual experience that deviates from the dominant plot lines and tells on the nature of metaphors that embody this experience.

In the conceptual metaphor theory, metaphor is addressed as "understanding and experiencing one kind of thing in terms of another" (Lakoff, \& Johnson, 1980, p. 5). More specifically, conceptual metaphor is described as a product of conceptual mapping, i.e. a partial and unidirectional projection of a more concrete conceptual structure (the source concept/domain) that we employ for the purposes of understanding onto a more abstract conceptual structure that we try to understand (the target domain) (Lakoff, 1993; Kövecses, 2002, 2018). Thus, in case of the TRANSITION IS JOURNEY/TRAVEL conceptual metaphor, TRANSITION is the target concept of high complexity that we try to explain with the help of a more familiar and better-structured source concept of JOURNEY/TRAVEL.

As to the narrative metaphor, though the term itself is widely used, the phenomenon behind it has not yet received a comprehensive definition. In this study, narrative metaphor is addressed as extended conceptual metaphor, which is distinguished by conceptual coherence based on cohesive links between its linguistic expressions in the textual context of a certain narrative. A typical conceptual metaphor is instantiated in a number of linguistic units used in different contexts and connected by abstract relations between concepts they activate in our mind. Contrary to that, a narrative metaphor is instantiated in linguistic expressions that activate concepts that are connected, i.e. made coherent, by the linguistic, social, cultural, and historical context of a narrative, and also by its immediate situational context. As any conceptual metaphor, any narrative metaphor can have multimodal representation.

\section{Method}

This research rests on 16 TED talks by transgender people posted on the TED platform within the period between January 2013 and July 2020 (TED, s. a.). TED (Technology, Entertainment, and Design) is an American media organisation that holds conferences under the slogan "ideas worth spreading", and posts conference talks on scientific, cultural, political, humanitarian and academic topics online for 
free distribution. The analysed talks are presented by the speakers aged from 20 to 70; 8 males and 8 females; 2 black and 9 white Americans, 2 Filipinos, 1 black South-African, 1 Puerto Rican, and 1 white Australian. Out of the 16 analysed talks, 6 are completely devoted to the speakers' transition experience. The 6 talks include those by D-L. Steward, a black American scholar; Hari Nef, a white American actress, model, and writer; LB Hannahs, a white American educator; Lee Mokobe, a black South-African poet; Geena Rocero, a professional Filipino model; and Paula Stone Williams, a white American evangelist pastor (TED, s. a.). The rest 10 talks focus on other topics, connected with the problems faced by transgender people, but include transition narrative as their integral part. They are presented by Karissa Sanbonmatsu, a white American epigeneticist; Samy Nour Younes, a Puerto Rican transgender activist; France Villarta, a Filipino communications consultant; Jenna Veiner, a white American scholar; Kate Stone, a white Australian artist; Jackson Bird, a white American digital storyteller; Ivan Coyote, a white American writer, and performer; iO Tillett Wright, a white American child actor; Martine Rothblatt, a white American transhumanist; and Tiq Milan, a black American transgender activist (TED, s. a.).

Compared to a narrative interview, which is a common object of analysis in narrative psychology, a TED talk has some advantages. Narrative interviewers have to use special strategies with some interviewees to make them produce extensive stories, they need to be aware of their own role in shaping those stories through influencing the interviewees, and, on the other hand, control their questions and reactions not to discourage the interviewees. Finally, interviewers have to compile a story based on their interview. As a result, stories born in narrative interviews may represent the identity of the interviewee through the lens of the interviewer. Contrary to that, a TED talk is a well-shaped persuasive story of constructing one's identity that is aimed at sharing personal experience and getting a response.

Methodologically, narrative can be approached from three distinct perspectives: formal-structural, content, and hermeneutic (László, 2015, p. 3). Formal-structural analysis concentrates on the structural components of narratives. Content analysis tries to quantify the semantic content of narratives. Hermeneutic analysis "embraces the social, cultural and textual content of the narrative and interprets its meaning against this background. In psychology it mostly means interpretation of personal narratives with reference to identity" (ibid.). Formalstructural and content approaches are criticised for being blind to the contexts in which structural and semantic components of narratives occur, while hermeneutic analysis is blamed for being not amenable to the empirical testing.

In this research, narrative is investigated with the instruments of conceptual metaphor theory that are adapted to study narrative metaphor. However, the results of analytical cognitive analysis are interpreted within the assumptions of psycholinguistics supporting the intersubjective model of linguistic meaning. Such approach qualifies as qualitative hermeneutic analysis since it takes into consideration not only linguistic (textual), social, cultural and historical content of the narrative, but also its intersubjective situational context. 
In addition, elements of formal-structural analysis are applied. To make sure that the TED talks chosen for the analysis are narratives I investigate whether they contain the three conceptual elements that are common to most narratives (after Plummer, 1995): a) suffering that gives tension to a story, b) a crisis or a turning point or epiphany, c) a transformation.

To define the structural components of the analysed narratives I employ Labov's (1972) linguistic representation of the narrative structure breaking it into six interconnected components (clauses): abstract (summarising), orientation (setting the scene), complicating action (giving central details), evaluation (expressing evaluation of the details), and coda (reflecting on the narrative as a whole). On top of that, I classify the analysed narratives based on Plummer's (1995) classification of modernist plots, which includes: a) taking a journey, b) engaging in a contest, c) enduring suffering, d) pursuing consummation, and e) establishing a home (ibid.). The plot categories themselves are addressed as narrative conceptual metaphors, representing TRANSITION in terms of the corresponding conceptual domains.

As a rule, the key narrative metaphor is first verbalised in an utterance found in the orientation clause and then instantiated in linguistic expressions scattered in all the other components of the narrative. Following this assumption, I first find the key utterance, summing up the content of the narrative in a metaphorical form and then look for other expressions connected with it by cohesive and coherent links.

The results of the analysis are reported in the form of a case study of a TED talk (Stewart, 2019) that represents a transition narrative of a Black transgender woman transitioning to man. This talk is chosen for the case study because the narrator belongs to the most vulnerable category of transgender people facing unacceptance from representatives of the most social categories, and his transition experience reflects all the traumatic issues that face a transgender person in concentrated form. The case study is complemented by the findings based on the analysis of the rest 15 narratives. To strengthen the results obtained the statistical formula of keyword density is employed $(N k r / T k r) * 100$, where $N k r$ is how many times a word/phrase is repeated in a text, and $T k r$ is the total number of words in a text (Taniar et al, 2010, p. 212). The words and phrases instantiating the TRANSITION metaphor in all the 16 narratives are retrieved and calculated manually. To interpret the calculated density I rely on the expert opinion that optimal keyword density should be 1 to $3 \%$ (ibid.).

\section{Results and Discussion}

The chosen TED talk (Stewart, 2019) qualifies as a narrative since it contains all of its basic structural components defined by Labov (1972), though not all of them are arranged in a linear sequence: orientation precedes the abstract.

The talk starts with orientation: the narrator introduces himself as D-L. Stewart, a faculty member at Colorado State University, and declares that he identifies himself as both Black and transgender. Orientation turns into abstract 
when the narrator states the topic of the talk: how Black trans lives matter. This utterance expresses determination to prove the importance of Black lives to others who might not be aware of this or might not want to see it. Moreover, as such it implies conflict. It is repeated 14 times in the talk to produce suggestive effect on the audience. On top of that, the narrator explains that he is going to share a few scenes from his own life and bring to light how race and gender have historically and currently intersected to shape the lives of Black trans people. Complicating action that occupies most of the talk is mixed with evaluation because the narrator's individual story is put into a broad social, cultural and historical context and therefore it is ideologically and axiologically charged. Coda is realized as an appeal to work together to make Black trans lives matter.

The analysed talk has the three constitutive semantic features of a narrative (after Plummer, 1995). Most of the talk is devoted to description and analysis of the suffering Black people in general and transgender Black people in particular have been going through due to their unacceptance by the society. The turning point is represented as realisation that the solution is in creating an alternative narrative that would set Black trans people free from social acceptability. Transformation is realized not as a fact but as a challenge, an appeal to the audience to transform their thinking about blackness and gender, and confront false assumptions and other's fears and biases.

The analysed narrative is conceived as an instantiation of the TRANSITION IS CONTEST narrative metaphor. Contest, which literary means "opposing (an action or theory) as mistaken or wrong" (Oxford English dictionary, s. a.) or "a struggle to win power and control" (Collins online dictionary, s. a.), metaphorically represents a conflict between the individual's experience of their gender identity and its assessment by the society.

Actually, all the 16 transition narratives analysed in the study are instantiations of the CONTEST metaphor. All of them highlight OTHERS either as the source of trauma caused by the social unacceptance or as the source of cure supplied by those who accepted them. The density of words and phrases that instantiate the CONTEST metaphor in the 16 analysed narratives varies from 2,5 to $3 \%$ which means that they are key linguistic expressions of the narratives.

In D-L. Stewart's talk the TRANSITION IS CONTEST narrative metaphor is expressed by the key utterance, My body defies the restrictions of a society consumed by boxes and binaries and 'are you a boy or a girl?' found in the orientation clause. Using the noun body as the subject of the sentence correlating with the doer of the action expressed by the verb defies, the speaker metonymically refers to himself as a member of the transgender category, a LIVING BEING, capable of defiance. At the same time, he metaphorically represents himself as a CONTAINER (human bodies are typically conceived as containers (Lakoff, \& Johnson, 1980)) and a building block of the SOCIETY conceptualised as a SET OF CONTAINERS since boxes actually are containers and binaries suggest dividing into parts, or categorising. Moreover, using the verb-predicate consumed with the nouns boxes and binaries as its subjects, the speaker represents SOCIAL CATEGORIES as AGGRESSIVE 
CREATURES capable of eating and digesting society members so that nothing remains but a set of boxes-containers in which the society members are put.

In addition to the key utterance, the TRANSITION IS CONTEST narrative metaphor is instantiated in other cohesive linguistic expressions that can be found in all the structural parts of the narrative. All these expressions presuppose two counteragents: the transgender INDIVIDUAL or his social category (I, Black trans people / lives / bodies, my body, my fellows, and so on) and the SOCIETY or social categories of OTHERS (mostly implied by the passive construction, or given metonymically, e.g., social acceptability, white imagination, social boundaries rather than explicitly named, e.g., society, my therapist).

The transgender individual is conceptualised as the subject of actions aimed at destroying societal boundaries. These actions are denoted by such linguistic units as resist ( 8 - in brackets here and hereafter I give the number of times a linguistic unit is repeated in the narrative) / resistance (8), transgress (4) / be transgressive (4), fight (2), claim sovereignty (2), push (1), set free (1), confront (1).

On the other hand, the transgender individual is conceived as the object of the society's counteractions expressed by the passive construction with make (12), deny (7) I denial (1), catch (4), contain (3), define (3), erase (2), mark (2), block (1), accuse (1), sissify (1), bulldagger (1), impose (1), murder (1), put in place (1), inoculate (1), accuse (1).

As any other social categorisation, gender categorisation goes hand in hand with biased evaluation. The speaker conceives his body as a sovereign country, where sovereign is interpreted as superlative in quality, of the most exalted kind, having generalized curative powers of an unqualified nature, unmitigated, paramount, possessed of supreme power, unlimited in extent, absolute, enjoying autonomy, independent, royal, characterised by magic.

This positive self-evaluation stands in striking contrast with the negative evaluation by the society. Being a Black transgender woman who has found her true male identity, the speaker is subject to a biased negative evaluation from the members of too many categories of OTHERS. The categorical oppositions highlighted in the narrative include those of white people :: black people, white women :: black women, black men :: black women, straight black people :: :: transgender black people, white transgender people :: black transgender people. Within these oppositions Black people are conceived as CAPTIVES (Black bodies and our genders have been caught in the white imagination), FUGITIVES (We have always been fugitives here), SLAVES (Body measurements taken, talents and abilities advertised, teeth and body cavities inspected, name and value assigned. This is a slave's bill of sale). They are dehumanised and turned into KEPT ANIMALS (and so we have been bred like horses, [...] branded like cattle, milked like sows) or even FOOD FOR KEPT ANIMALS (fed like turtles to alligators). They are reified and turned into OBJECTS (Imagined as a thing, we were made to become that thing), and GOODS (Gender did not matter, so long as our body parts, our arms and legs and backs, our breasts and genitalia could be turned into profit). 
The narrator puts evaluation of a Black (trans) person's gender identity into the broad context of cultural African American archetypes and stereotypes that date back to the colonial history of the United States: From mammy and Sapphire, to Mandingo and Sambo, Black bodies and our genders have been caught in the white imagination. The Mammy archetype refers to a dominant female house slave: a woman completely dedicated to the family of her white enslavers (White, 1999). The Sapphire archetype describes a domineering female who consumes men and usurps their roles (ibid.). Its contemporary manifestation is the "angry black woman" stereotype, which was exploited by journalists in their narratives about Michelle Obama during the 2007-2008 presidential primaries. The Sambo stereotype was introduced into American culture by a character of the 1898 children's book "The story of little black Sambo" by Helen Bannerman. It represents black men as lazy, irresponsible, or carefree. Finally, the Mandingo is a stereotype of a sexually voracious black man with a huge penis (Davis \& Cross, 1979). It implies uncontrolled passions, ambitions, and associates with black bestiality and primitivism. These associations explain why a black woman is often represented as either beast or porn star, made a social threat that endangers civility.

These metaphors highlight suffering of human beings caused by other humans, which gives these metaphors a great empathic power of agentive nature, i.e. they are aimed at transforming people's thinking and challenging them to social action to change the inhuman into human. This agentive power is enhanced by the awareness that the narrator who is standing here and now before the audience is part of this social injustice. This awareness triggered by the immediate situational context of the narrative transforms abstract notions into real events involving real people; it includes the audience into the narrative and gives them power to change it. Narrative intertwines with real life.

In all the analysed narratives, the power of words is multiplied by the power of visual representation of transgender speakers who make declarations of their transgender identity not only through the choice of words but also through the choice of their outfits. A good example is the narrative of a transgender epigeneticist (Sanbonmatsu, 2018) who has discovered and constructed her new female identity. A huge part of her narrative about what it means to be a woman on the DNA level is conveyed by the deep neckline of her otherwise reserved outfit, which slightly reveals the upper part of her beautiful breasts. In the context of the narrative, this image represents the healed trauma, and the conquered social denial. In other words, it constitutes the CONTEST metaphor in its final VICTORY phase, that of celebrating the newly found gender self.

\section{Conclusion}

The research findings lead to the following conclusions.

Firstly, within the intersubjective psycholinguistic approach to meaning making, narrative metaphor is seen as extended conceptual metaphor that is instantiated in 
multimodal (primarily linguistic and visual) metaphoric expressions, which are given coherence by the textual, social, cultural, and historical context of the narrative, on the one hand, and by its interactive situational context, on the other hand. All separate verbal and visual conceptual metaphors, brought together into one narrative metaphor by coherent contextual links address the phenomenon of gender transition in a very powerful way, activating a web of rational inferences, emotional reactions, and intuitive associations that have a great agentive potential, i.e. the power to influence the recipients through empathy.

Secondly, all the 16 analysed narratives instantiate the TRANSITION IS CONTEST narrative metaphor that represents a conflict between a transgender individual and the society that does not accept them. This conflict results in the traumatic nature of transition experience.

Thirdly, narrative as well as narrative metaphor can be given a more consistent interpretation if they are approached from the intersubjective perspective, which reflects their true nature as socially and culturally shaped interactive phenomena.

The results achieved call for further investigation of narrative phenomena based on the psycholinguistic intersubjective methodology that helps reveal how historical, cultural, social as well as situational interactive contexts shape individual experiences.

\section{References}

Aizura, A. Z. (2012). The persistence of transgender travel narratives. In T., Cotten (Ed.).

Transgender migrations: The bodies, borders, and politics of transition (pp. 139-156). New

York \& London, UK: Routledge.

Arenas, E. S. \& Essam, B. A. (2018). Cognitive exploration of 'Traveling' in the poetry of Widad Benmoussa. East European Journal of Psycholinguistics, 5(2), 6-15. https://doi.org/10.29038/eejpl.2018.5.2.are

Bodoin, E.R., Berd, C.T., \& Adler, R.K. (2014). The clinical profile of the male-to-female transgender person of the 21st century. Journal of Speech, Language, and Hearing Research 41, 39-54. https://doi.org/10.1044/cicsd_41_S_39

Booz, J., Dorman, K., \& Walden, P. (2017). First-person narratives by transgender individuals on voice and communication. Journal of Speech, Language, and Hearing Research 2(10), 60-63. https://doi.org/10.1044/persp2.SIG10.60

Bruner, J. (1986). Actual minds, possible worlds. Cambridge, MA: Harvard University Press.

Bruner, J. (1987). Life as narrative. Social Research, 54(1), 11-32. https://doi.org/:10.2307/40970444

Bruner, J. (1990). Acts of Meaning. Cambridge, MA: Harvard University Press.

Davis, G.L. \& Cross, H.J. (1979). Sexual stereotyping of Black males in interracial sex. Archives of Sexual Behavior, 8(3), 269-279. https://doi.org/10.1007/BF01541243

Gallagher, S. (2005). How the Body Shapes the Mind. Oxford, UK: Oxford University Press.

Halberstam, J. (1998). Female Masculinity. Durham \& London, UK: Duke University Press.

Hardy, C. (1998). Networks of Meaning: A Bridge Between Mind and Matter. Wesport, CT \& London, UK: Praeger.

Hardy, T. L. D., Boliek, C. A., Aalto, D., Lewicke, J., Wells, K., \& Rieger, J. M. (2020). Contributions of voice and nonverbal communication to perceived masculinity femininity for cisgender and transgender communicators. Journal of Speech, Language, 
and Hearing Research 63(4), 931-947. https://doi. org/10.1044/2019 JSLHR-19-00387

Hines, S. (2007). Transforming Gender: Transgender Practices of Identity, Intimacy, and Care.

Bristol, UK: Bristol University Press.

Heath, R. A. (2006). The Praeger Handbook of Transsexuality: Changing Gender to Match mindset. Westport, CT: Praeger

Koch-Rein, A. (2014). Mirrors, monsters, metaphors: transgender rhetorics and dysphoric knowledge. Ph.D. dissertation. Retrieved from https://etd.library.emory.edu/concern/etds/0v838098q?locale=it

Kövecses, Z. (2002). Metaphor: A Practical Introduction. Oxford, UK: Oxford University Press.

Kövecses, Z. (2018). Metaphor in media language and cognition: A perspective from conceptual metaphor theory. Lege Artis. Language Yesterday, Today, Tomorrow, 3(1), 124141. https://doi/org/10.2478/lart-2018-0004

Labov, W. (1972). The transformation of experience in narrative syntax. In W., Labov (Ed.). Language in the inner city: Studies in the Black English vernacular (pp. 354-396). Philadelphia, PA: University of Pennsylvania Press.

Lakoff, G. (1993). The contemporary theory of metaphor. In A., Ortony (Ed.). Metaphor and Thought. 2nd ed., (pp. 202-251). Cambridge, UK: Cambridge University Press.

Lakoff, G., \& Johnson, M. (1980). Metaphors We Live By. Chicago, IL: University of Chicago Press.

László, J. (2015). The Science of Stories: An Introduction to Narrative Psychology. New York, NY: Routledge.

Lederer, J. (2015). Exploring the metaphorical models of transgenderism. Metaphor and Symbol 30(2), 95-117.

Martynyuk, A. (2017). "Now that the magic is gone" or toward cognitive analysis of verbal/co verbal communication. Cognition, Communication, Discourse, 15, 51-72. https://doi.org/10.26565/2218-2926-2017-15-04

Murray, M. (2003). Narrative psychology and narrative analysis. In P.M. Camic, J.E. Rhodes, \& L. Yardley (Eds.). Qualitative research in psychology: Expanding perspectives in methodology and design (pp. 95-112). Washington, DC: American Psychological Association.

Plummer, K. (1995). Telling Sexual Stories: Power, Change, and Social Worlds. N.Y.: Routledge.

Polkinghorne, D. E. (1988). Narrative Knowing and the Human Sciences. N.Y.: State University of New York Press.

Prosser, J. (1998). Second Skins: The Body Narratives of Transsexuality. N.Y.: Columbia University Press.

Ricoeur, P. (1989). Time and narrative. Volume 3. Chicago, IL: University of Chicago Press.

Riley, D. (2000). The words of Selves. Identification, Solidarity, Irony. Stanford, CA: Stanford University Press.

Sarbin, T. R. (1986). The narrative as root metaphor for psychology. In T.R. Sabrin

(Ed.). Narrative psychology: The storied nature of human conduct (pp. 3-21). N.Y.: Praeger.

Salamon, G. (2010). Assuming a Body: Transgender and Rhetorics of Materiality.

N.Y.: Columbia University Press.

Taniar, D., Gervasi, O., Murgante, B., Apduhan, B. O., \& Pardede, E. (Eds.) (2010). International Conference on Computational Science and Its Applications. ICCSA 2010.

Proceedings. Fukuoka, Japan: Springer Science \& Business Media. Retrieved from https://archive.org/details/computationalsci0000tani/page/212/mode/2up

Thompson, E. (2007). Mind in Life: Biology, Phenomenology, and the Sciences of Mind.

Cambridge, MA: Harvard University Press. 
Trevarthen, C. (1998). The concept and foundations of infant intersubjectivity. In S. Bråten

(Ed.). Intersubjective communication and emotion in early ontogeny (pp. 15-46).

Cambridge, UK: Cambridge University Press.

White, D. G. (1999). Ar'n't I a Woman?: Female Slaves in the Plantation South.

N.Y.: W.W. Norton \& Company.

Zahavi, D. (2005) Intersubjectivity and Selfhood: Investigating the First Person Perspective. Cambridge, MA: The MIT Press.

Zalevskaya, A. A. (2014). Interfejsnaya Teoriya Znacheniya Slova: Psiholingvisticheskij Podhod [Interfacial Theory of Word Meaning: A Psycholinguistic Approach]. London: IASHE.

Zlatev, J., Racine, T., Sinha, C., \& Itkonen, E. (Eds.). (2008). The Shared Mind: Perspectives on Intersubjectivity. Amsterdam, NL: John Benjamins.

\section{Sources}

Cambridge Dictionary. Retrieved from https://dictionary.cambridge.

Collins Online Dictionary. Retrieved from https://www.collinsdictionary.com.

Oxford English Dictionary. Retrieved from https://www.lexico.com.

Sanbonmatsu, K. (2018, November). The biology of gender, from DNA to the brain. Retrieved from https://www.ted.com/talks/karissa_sanbonmatsu_the biology_of_gender_from dna_to_the_brain

Stewart, D-L. (2019, March). Scenes from a Black trans life. Retrieved from https://www.ted.com/talks/d_1_stewart_scenes_from_a_black_trans_life

TED. Ideas worth spreading. Retrieved from

https://www.ted.com/talks?topics\%5B\%5D=Transgender 